\title{
6. Neue Literatur
}

\section{Otmar Jung unter Mithilfe aller Herausgeber}

Ahlfeldt, Gabriel M./Maennig, Wolfgang: Homeownership and NIMBYism: A Spatial Analysis of Airport Effects, London 2011 (SERC Discussion Paper No. 85).

Aker, Bernd: Instrumente direkter Demokratie - Bürgerbegehren und Bürgerentscheid: Entwicklung in Gesetzgebung und Rechtsprechung, in: VBlBW 32 (2011), S. 455-457.

Alber, Elisabeth: Ethnic Governance and Direct Democracy: Perils and Potential, in: Marxer, Wilfried (Hrsg.): Direct Democracy and Minorities, Wiesbaden 2012 (Direct Democracy in Modern Europe), S. 74-87.

v. Arnim, Hans Herbert/Schmid, Georg: Direktwahl der Ministerpräsidenten? Pro und Kontra, in: Politik \& Kommunikation 2012, Mai, S. 10.

Assenbrunner, Benedikt: Die praktische Umsetzung der Europäischen Bürgerinitiative nach dem Vertrag von Lissabon, in: SächsVB1. 19 (2011), S. 201-204.

Audoye, Benjamin: Les votations à l'initiative des collectivités territoriales et des groupements de communes, Toulouse 2011.

Badura, Peter: Plebiszitäre Ergänzung oder Verformung des parlamentarischen Regierungssystems in der Bundesverfassung, in: Ruffert, Matthias (Hrsg.): Dynamik und Nachhaltigkeit des Öffentlichen Rechts. Festschrift für Professor Dr. Meinhard Schröder zum 70. Geburtstag, Berlin 2012, S. 307-318.

Balthasar, Alexander: The European Citizens' Initiative: an instrument rather of deliberative than of participatory democracy?, in: Pichler, Johannes W./Kaufmann, Bruno (Hrsg.): Modern transnational democracy. How the 2012 launch of the European Citizens' Initiative can change the world, Wien u.a. 2012 (Schriften zur Rechtspolitik Bd. 33), S. 33-43.

Baus, Ralf Thomas/Montag, Tobias (Hrsg.): Perspektiven und Grenzen „direkter Demokratie“, Sankt Augustin 2012.

Beath, Andrew/Christia, Fotini/Enikolopov, Ruben: Direct Democracy and Resource Allocation. Experimental Evidence from Afghanistan, Washington D.C. 2012 (World Bank Policy Research Working Paper No. 6133).

Bender, Christiane: Freiheit, Verantwortung, direkte Demokratie: zur Relevanz von Rousseau heute, in: APuZ 62 (2012), 46/47, S. 49-54.

Benedikter, Thomas: Direct Democracy and Linguistic Minorities in Switzerland and South Tyrol - A Comparison, in: Marxer, Wilfried (Hrsg.): Direct Democracy and Minorities, Wiesbaden 2012 (Direct Democracy in Modern Europe), S. 106-122.

Bernhard, Laurent: Campaign strategy in direct democracy, Basingstoke 2012.

Bernhard, Laurent: Direkte Demokratie wagen? Eine Bestandsaufnahme der Chancen und Gefahren, in: Neue soziale Bewegungen 25 (2012), S. 47-54.

Bernhard, Laurent: Message Delivery, in: Kriesi, Hanspeter (Hrsg.): Political Communication in Direct Democratic Campaigns: Enlightening or Manipulating?, Basingstoke u.a. 2012 (Challenges to Democracy in the 21st Century), S. 82-92.

Bernhard, Laurent/Kriesi, Hanspeter: Coalition Formation, in: Kriesi, Hanspeter (Hrsg.): Political Communication in Direct Democratic Campaigns: Enlightening or Manipulating?, Basingstoke u.a. 2012 (Challenges to Democracy in the 21st Century), S. 54-68. 
Bertrams, Michael: Bürgerbeteiligung bei Großprojekten, in: NWVBl. 26 (2012), S. 289-293.

Biaggini, Giovanni: Eine verzwickte Angelegenheit. Die nachträgliche Überprüfung der Regularität einer eidgenössischen Volksabstimmung. Bemerkungen zu den Entscheidungen des Bundesrates (vom 29. Juni 2011) und des Bundesgerichts (vom 20. Dezember 2011) in Sachen Volksabstimmung über das „Unternehmenssteuerreformgesetz II“ vom 24. Februar 2008, in: Schweizerisches Zentralblatt für Staats- und Verwaltungsrecht 113 (2012), S. 429-441.

Blankart, Charles B./Margraf, Simon: Taxing Expats. Instrumental versus Expressive Voting Compared, München 2011 (CESifo Working Paper No. 3627).

Blot, Yvan: La démocratie directe. Une chance pour la France, Paris 2012.

Blume, Lorenz: Institutional details matter: more economic effects of direct democracy, in: Economics of Governance 13 (2012), S. 287-310.

Blume, Lorenz/Doering, Thomas/Voigt, Stefan: Fiscal Effects of Reforming Local Constitutions: Recent German Experiences, in: Urban Studies 48 (2011) 10, S. 2123-2140.

Böckenförde, Markus: Die Einbindung der Bevölkerung in Verfassungsänderungsprozessen ein Überblick, in: Hestermeyer, Holger P. u.a. (Hrsg.): Coexistence, Cooperation and Solidarity, Bd. 2. Liber Amicorum Rüdiger Wolfrum, Leiden 2012, S. 1107-1123.

Böhm, Monika: Die direkte Demokratie in der Schweiz - Ein Vorbild für Deutschand?, in: DÖV 66 (2013), S. 1-7.

Bökenkamp, Gérard: Liberale Perspektiven auf die Chancen und Risiken der ,direkten Demokratie“, in: Baus, Ralf Thomas/Montag, Tobias (Hrsg.): Perspektiven und Grenzen „direkter Demokratie“, Sankt Augustin 2012, S. 25-34.

Bonfadelli, Heinz/Friemel, Thomas N.: Learning and Knowledge in Political Campaigns, in: Kriesi, Hanspeter (Hrsg.): Political Communication in Direct Democratic Campaigns: Enlightening or Manipulating?, Basingstoke u.a. 2012 (Challenges to Democracy in the 21 st Century), S. 168-187.

Boninu, Marco: La democrazia deliberativa: costituzione e volontà generale, Rom 2012.

Bougheas, Spiros/Nelson, Doug: On the Political Economy of High Skilled Migration and International Trade, München 2012 (CESifo Working Paper No. 3880).

Breen, Michael J.: The influence of mass media on divorce referenda in Ireland, Lewiston 2010.

Breig, Burkhard: Sachunmittelbare Demokratie in Russland, in: Neumann, Peter/Renger, Denise (Hrsg.): Sachunmittelbare Demokratie im interdisziplinären und internationalen Kontext 2010/2011. Mittel- und Osteuropa, Baden-Baden 2012 (Studien zur Sachunmittelbaren Demokratie Bd. 11), S. 255-308.

Brügger, Emanuel/von Wyss, Moritz: Parlament und konstruktives Referendum. Aktuelle Diskussion im Kanton Zürich, in: Parlament 14 (2011), S. 29-30.

Brusis, Martin: Direkte Demokratie in Südosteuropa - Ist unmittelbare Demokratie in jungen Staaten dienlich?, in: Neumann, Peter/Renger, Denise (Hrsg.): Sachunmittelbare Demokratie im interdisziplinären und internationalen Kontext 2010/2011. Mittel- und Osteuropa, Baden-Baden 2012 (Studien zur Sachunmittelbaren Demokratie Bd. 11), S. 83-97.

Buechi, Rolf: Use of Direct Democracy in the Jura Conflict, in: Marxer, Wilfried (Hrsg.): Direct Democracy and Minorities, Wiesbaden 2012 (Direct Democracy in Modern Europe), S. 181-193.

Carey, John M./Hix, Simon: District magnitude and representation of the majority's preferences: a comment and reinterpretation, in: Public Choice 154 (2013), S. 139-148. 
Cebula, Richard J./Coombs, Christopher K.: The influence of the number of statewide legislative referendums on voter participation in the US, in: Applied Economics 43 (2011), S. 2823-2831.

Cede, Franz: The Plebiscites in Carinthia and Sopron-Ödenburg after World War I - two Cases of Direct Democracy in Action, in: Marxer, Wilfried (Hrsg.): Direct Democracy and Minorities, Wiesbaden 2012 (Direct Democracy in Modern Europe), S. 15-21.

Centre d'études costitutionnelles et politiques (Hrsg.): Théorie et pratiques du référendum: actes de la journée d'étude du 4 novembre 2011, Paris 2012.

Chollet, Antoine: Défendre la démocratie directe: sur quelques arguments antidémocratiques des élites suisses, Lausanne 2011.

Christmann, Anna: Das Vorbild unter der Lupe: Sachunmittelbare Demokratie in der Schweiz, in: Neumann, Peter/Renger, Denise (Hrsg.): Sachunmittelbare Demokratie im interdisziplinären und internationalen Kontext 2009/2010. Deutschland, Liechtenstein, Österreich, Schweiz und Europa, Baden-Baden 2012 (Studien zur Sachunmittelbaren Demokratie Bd. 9), S. 154-175.

Christmann, Anna: Die Grenzen direkter Demokratie. Volksentscheide im Spannungsverhältnis von Demokratie und Rechtsstaat, Baden-Baden 2012 (Politik und Demokratie in den kleineren Ländern Europas Bd. 2).

Christmann, Anna: Direct Democracy and the Rule of Law - Assessing a Tense Relationship, in: Marxer, Wilfried (Hrsg.): Direct Democracy and Minorities, Wiesbaden 2012 (Direct Democracy in Modern Europe), S. 47-63.

Christmann, Anna: Politicians as judges? Conflict of interest in swiss parliament during decisions on the validity of popular votes, in: Peters, Anne/Handschin, Lukas (Hrsg.): Conflict of interest in global, public and corporate governance. Cambridge/MA 2012, S. 198216.

Christmann, Anna/Danaci, Deniz: Direct Democracy and Minority Rights. Direct and Indirect Effects on Religious Minorities in Switzerland, in: Politics and Religion 5 (2012), S. $133-160$.

Criblez, Lucien: Vox populi - zur Herausforderung der Bildungspolitik durch die halbdirekte Demokratie, in: Zeitschrift für Pädagogik 57 (2011), S. 471-483.

Danaci, Deniz: Die Macht sozialer Identitäten: Einstellungen und Abstimmungsverhalten gegenüber Minderheiten in der Schweiz, Baden-Baden 2012 (Politik und Demokratie in den kleineren Ländern Europas Bd. 3).

Danaci, Deniz: The Minaret Ban in Switzerland: An Exception to the Rule?, in: Marxer, Wilfried (Hrsg.): Direct Democracy and Minorities, Wiesbaden 2012 (Direct Democracy in Modern Europe), S. 155-164.

Daugeron, Bruno: Un référendum d'initiative partagée sur le „,mariage homosexuel“ est-il possible?, in: Recueil Dalloz 188 (2012), S. 2613-2614.

Decker, Frank: Der Irrweg der Volksgesetzgebung. Warum die direkte Demokratie in den Ländern kein Vorbild für die Bundesebene sein kann, in: ZSE 9 (2011), S. 473-500.

Decker, Frank: Die fehlgeleitete Debatte um den Volksentscheid auf Bundesebene, in: Vorgänge 51 (2012), S. 26-34.

Decker, Frank: Möglichkeiten und Grenzen der direkten Demokratie: das Beispiel Stuttgart 21, in: Braun, Stephan (Hrsg.): Die verstimmte Demokratie. Moderne Volksherrschaft zwischen Aufbruch und Frustration, Wiesbaden 2012, S. 209-217. 
Decker, Frank: Sachunmittelbare Demokratie auf der Ebene der Länder, in: Neumann, Peter/Renger, Denise (Hrsg.): Sachunmittelbare Demokratie im interdisziplinären und internationalen Kontext 2009/2010. Deutschland, Liechtenstein, Österreich, Schweiz und Europa, Baden-Baden 2012 (Studien zur Sachunmittelbaren Demokratie Bd. 9), S. 29-47.

Decker, Frank: Welche Art der direkten Demokratie brauchen wir? In: Mörschel, Tobias/Krell, Christian (Hrsg.): Demokratie in Deutschland. Zustand - Herausforderungen - Perspektiven, Wiesbaden 2012, S. 175-198.

Degen, Bernard: Art. Referendum, in: Stiftung Historisches Lexikon der Schweiz (Hrsg.): Historisches Lexikon der Schweiz, Bd. 10, Basel 2011, S. 166-168.

Degenhardt, Mathias: „Eichsfelder aller Schichten sagen Ja“: das Eichsfeld in der Abstimmung zum Friedensvertrag; eine Episode im Kalten Krieg, in: Eichsfelder Heimatzeitschrift 56 (2012), S. 201-204.

Der Präsident des Landtags Rheinland-Pfalz (Hrsg.): Volksentscheide, Demokratie und Rechtsstaat. Das rheinlandpfälzische Reformprojekt „mehr Bürgerbeteiligung wagen“ im Lichte schweizerischer und deutscher Erfahrungen. Diskussionsveranstaltung in der Reihe „Partner im Dialog“ am 14. Juni 2011 im Landtag Rheinland-Pfalz, Mainz 2011.

Dinu, Alina u.a.: Le projet européen face à la démocratie participative, Straßburg 2011.

Dostie, Benoit: „The people's will“: Canadians and the 1898 referendum on alcohol prohibition, in: Explorations in Economic History 49 (2012), S. 498-515.

Drobny, Josef: Abstimmung in Oberschlesien. Eine besondere Botschaft aus Tworkau im Ratiborer Land, Leverkusen 2012.

Dreier, Horst: Das Volk als Gesetzgeber. Mehr direkte Demokratie in Deutschland - wäre das mit dem Grundgesetz vereinbar?, in: SZ Nr. 47 v. 25./26.2.2012, S. 16.

Drevs, Florian: Die Einstellung gegenüber staatlich finanzierten Informationsmaterialien: Eine empirische Untersuchung am Beispiel der Volksabstimmung über Stuttgart 21, in: Zeitschrift für öffentliche und gemeinwirtschaftliche Unternehmen 35 (2012), S. 115-137.

Drewitz, Jan: Verändern Bürgerentscheide die Politik? Strukturelle und partizipatorische Auswirkungen direktdemokratischer Praxis, in: ZParl 43 (2012), S. 429-445.

Durinke, Peter Lothar: Bürgerentscheide in der Bauleitplanung. Zulässigkeit und Grenzen, Hamburg 2011 (Schriften zum Bau- und Vergaberecht Bd. 11).

Durinke, Peter: Zulässigkeit und Grenzen von Bürgerbegehren und Bürgerentscheiden in der Bauleitplanung, in: Zeitschrift für deutsches und internationales Bau- und Vergaberecht 35 (2012), S. 531-537.

Eisel, Stephan: Internet und „direkte Demokratie“, in: Baus, Ralf Thomas/Montag, Tobias (Hrsg.): Perspektiven und Grenzen ,direkter Demokratie“, Sankt Augustin 2012, S. 3549.

Eith, Ulrich/Mielke, Gerd/Oberndörfer, Dieter: Volksentscheide in der Parteiendemokratie Das Lehrstück Stuttgart 21, in: Berliner Republik 13 (2012), H. 1, S. 60-67.

Engelbrecht, Kai: Bürgerwille und Haushaltsgrundsätze. Art. 61 Abs. 2 Satz 1 BayGO als Determinante bei der Zulassung von Bürgerbegehren, in: BayVB1. 142 (2011), S. 617-624.

Fatke, Matthias: Die direkte Demokratie in Baden-Württemberg und Stuttgart 21, in: Der Bürger im Staat 62 (2012), S. 174-181.

Fauchard, Liam/Philippe, Mocellin: Démocratie participative: progrès ou illusions?, Paris 2012. 
Feld, Lars/Kirchgässner, Gebhard/Schaltegger, Christoph: Municipal Debt in Switzerland: New Empirical Results, Public Choice 149 (2011), S. 49-64.

Ferraro, Fabio: Il diritto di iniziativa dei cittadini europei: Uno strumento efficace di democrazia partecipativa?, in: Rivista italiana di diritto pubblico comunitario 21 (2011), S. 727745.

Fetzer, Joel S./Soper, J. Christopher: An ecological analysis of the 2009 Swiss referendum on the building of minarets, in: Helbling, Marc (Hrsg.): Islamophobia in the west: measuring and explaining individual attitudes, London 2012, S. 101-111.

Feuerstein, Nadine: Das Spannungsfeld von Initiativ- und Völkerrecht: Analyse und Lösungsansatz, Zürich 2012 (Wirtschaftsjuristische Arbeiten Bd. 4).

de Figueiredo, John/Ji, Chang Ho/Kousser, Thad: Financing Direct Democracy: Revisiting the Research on Campaign Spending and Citizen Initiatives, in: The Journal of Law, Economics, \& Organization 27 (2011), S. 485-514.

Figueroa, Portillo/Ulises, Edgar: Institucionalización del referéndum en México, Toluca 2012.

Frankenberger, Sebastian: Widerstand durch direkte Demokratie: aus der Sicht eines Aktivisten, in: v. Arnim, Hans Herbert (Hrsg.): Widerstand, Berlin 2012 (Schriftenreihe der Hochschule Speyer Bd. 215), S. 99-109.

Franzius, Claudio: Stuttgart 21: Eine Epochenwende?, in: GewArch. 58 (2012), S. 225-236.

Frey, Bruno S./Stutzer, Alois/Neckermann, Susanne: Direct democracy and the constitution, in: Marciano, Alain (Hrsg.): Constitutional mythologies: new perspectives on controlling the state, New York u.a. 2011, S. 107-119.

Friedrich, Dawid: Democratic participation and civil society in the European Union, Manchester 2011.

Funk, Patricia/Gathmann, Christina: Does Direct Democracy Reduce the Size of Government? New Evidence from Historical Data, 1890-2000, in: Economic Journal 121 (2011), S. 1252-1280.

Gärditz, Klaus Ferdinand: Angemessene Öffentlichkeitsbeteiligung bei Infrastrukturprojekten als Herausforderung an das Verwaltungsrecht im demokratischen Rechtsstaat, in: GewArch. 57 (2011), S. 273-279.

Galletta, Sergio/Jametti, Mario: How to Tame two Leviathans? Revisiting the Effect of Direct Democracy on Local Public Expenditure, München 2012 (CESifo Working Paper No. 3982).

Geissel, Brigitte: Evaluating democratic innovations. Curing the democratic malaise?, London u.a. 2012.

Gerth, Matthias A./Dahinden, Urs/Siegert, Gabriele: Coverage of the Campaigns in the Media, in: Kriesi, Hanspeter (Hrsg.): Political Communication in Direct Democratic Campaigns: Enlightening or Manipulating?, Basingstoke u.a. 2012 (Challenges to Democracy in the 21st Century), S. 108-124.

Glaser, Andreas: Das Verwaltungsreferendum: Betroffenenpartizipation zwischen demokratischer Legitimation und Rechtsstaat, in: Schweizerisches Zentralblatt für Staats- und Verwaltungsrecht 113 (2012), S. 511-536.

Glombik, Manfred: Aus dem ABC der Europäischen Union: Europäische Bürgerinitiative, in: Verwaltungsrundschau 58 (2012), S. 413-418.

Goerlich, Helmut: Das Europäische Bürgerbegehren nach dem Vertrag von Lissabon, in: Neumann, Peter/Renger, Denise (Hrsg.): Sachunmittelbare Demokratie im interdisziplinären und internationalen Kontext 2009/2010. Deutschland, Liechtenstein, Österreich, 
Schweiz und Europa, Baden-Baden 2012 (Studien zur Sachunmittelbaren Demokratie Bd. 9), S. 179-197.

Gräber, David: Critica della democrazia occidentale: nuovi movimenti, crisi dello stato, democrazia diretta, Mailand 2012.

Gross, Andreas: Direkte Demokratie. Die Neuerfindung einer Idee, Zürich 2012.

Grotz, Florian: Direkte Demokratie in Mittel- und Osteuropa. Befunde und Perspektiven des internationalen Vergleichs, in: Neumann, Peter/Renger, Denise (Hrsg.): Sachunmittelbare Demokratie im interdisziplinären und internationalen Kontext 2010/2011. Mittel- und Osteuropa, Baden-Baden 2012 (Studien zur Sachunmittelbaren Demokratie Bd. 11), S. $13-34$.

Gurlit, Elke: Neue Formen der Bürgerbeteiligung? Planung und Zulassung von Projekten in der parlamentarischen Demokratie, in: JZ 67 (2012), S. 833-841.

Hänggli, Regula: Key Factors in Frame Building, in: Kriesi, Hanspeter (Hrsg.): Political Communication in Direct Democratic Campaigns: Enlightening or Manipulating?, Basingstoke u.a. 2012 (Challenges to Democracy in the 21st Century), S. 125-142.

Hänggli, Regula/Bernhard, Laurent/Kriesi, Hanspeter: Construction of the Frames, in: Kriesi, Hanspeter (Hrsg.): Political Communication in Direct Democratic Campaigns: Enlightening or Manipulating?, Basingstoke u.a. 2012 (Challenges to Democracy in the 21st Century), S. 69-81.

Hänggli, Regula/Schemer, Christian/Rademacher, Patrick: Design of the Study: An Integrated Approach, in: Kriesi, Hanspeter (Hrsg.): Political Communication in Direct Democratic Campaigns: Enlightening or Manipulating?, Basingstoke u.a. 2012 (Challenges to Democracy in the 21st Century), S. 39-53.

Hafner, Simone: Die Beteiligung der Öffentlichkeit bei der Anpassung an die Folgen des Klimawandels, in: Natur + Recht 34 (2012), S. 315-321.

Hamon, Francis: Le référendum: étude comparative, 2. Aufl. Paris 2012.

Hamon, Francis: Référendum et réforme électorale au Royaume-Uni. Le rejet du vote alternatif, in: Revue française de droit constitutionnel 88 (2011), S. 759-780.

Hatori, Tsuyoshi: Knowledge, political innovation and referendum, in: Karlsson, Charlie (Hrsg.): The regional economics of knowledge and talent. Local advantage in a global context, Cheltenham u.a. 2012 (New horizons in regional science), S. 234-256.

Haug, Volker M.: Volksgesetzgebung auf verfassungsrechtlichem Neuland - Rechtsfragen im Zusammenhang mit der baden-württembergischen Volksabstimmung über das „S 21Kündi-gungsgesetz“, in: ZParl 43 (2012), S. 446-466.

Henke, Christoph Conrad: Direkte Demokratie auf Bundesebene: Probleme, Lösungsansätze, Einschränkungen, Berlin 2011 (Politik und Partizipation Bd. 6).

Henneke, Hans-Günter: Effizientere Erfüllung öffentlicher Aufgaben durch intensivierte bürgerschaftliche Mitwirkung?, in: ZG 27 (2012), S. 228-251.

Henneke, Hans-Günter: Wutbürger in Verantwortung: Partizipation und direkte Demokratie in Kommunen und Ländern, in: DVB1. 127 (2012), S. 1072-1082.

Hering, Steffen: Die spezielle Problematik von gegenläufigen Bürgerbegehren anhand eines Vergleichs zweier praktischer Beispiele aus der Landeshauptstadt München und der Marktgemeinde Garmisch-Partenkirchen, Hof 2012.

Heußner, Hermann K.: Die Krise Kaliforniens - Die Schuld der direkten Demokratie?, in: JdD 3 (2011), S. 175-233. 
Heußner, Hermann K.: Minorities and Direct Democracy in the USA: Direct Legislation Concerning Minorities and Instruments of Minority Protection, in: Marxer, Wilfried (Hrsg.): Direct Democracy and Minorities, Wiesbaden 2012 (Direct Democracy in Modern Europe), S. 123-144.

Hizen, Yoichi/Shinmyo, Masafumi: Imposing a turnout threshold in referendums, in: Public Choice 148 (2011), S. 491-503.

Hofmann, Klaus: Zur Zulässigkeit von Bürgerbegehren in Baden-Württemberg nach $§ 21$ Abs. 3 GemO - Aktuelle Tendenzen in der verwaltungsgerichtlichen Rechtsprechung, in: VBlBW 33 (2012), S. 371-379.

Hoffmann, Thomas: Sachunmittelbare Demokratie im Baltikum (Estland, Lettland, Litauen), in: Neumann, Peter/Renger, Denise (Hrsg.): Sachunmittelbare Demokratie im interdisziplinären und internationalen Kontext 2010/2011. Mittel- und Osteuropa, Baden-Baden 2012 (Studien zur Sachunmittelbaren Demokratie Bd. 11), S. 309-327.

Hofmann, Klaus: Befangenheit eines Gemeinderats wegen Unterzeichnung eines Bürgerbegehrens?, in: VB1BW 33 (2012), S. 460-462.

Hofmann, Klaus: Zur Zulässigkeit von Bürgerbegehren in Baden-Württemberg nach $§ 21$ Abs. 3 GemO. Aktuelle Tendenzen in der verwaltungsgerichtlichen Rechtsprechung und offene Fragen, in: VBlBW 33 (2012), S. 371-379.

Holland-Cunz, Barbara: Postdemokratie, Geschlechterdemokratie, Direkte Demokratie. Vom Ende des Paternalismus in der politischen Kultur, in: JdD 3 (2011), S. 65-77.

Hollander, Saskia/Leyenaar, Monique: Towards a Direct Democratic Era? Assessing the Usage of Direct Democratic Institutions in Europe, in: Gijsenbergh, Joris/Hollander, Saskia/ Houwen, Tim/de Jong, Wim (Hrsg.): Creative Crises of Democracy, Berlin/Frankfurt a.M. 2012 (Philosophy \& Politics Bd. 23), S. 399-419.

Holzner, Thomas: Verfassungsänderung in Bayern? Anmerkungen zur Direktwahl des Ministerpräsidenten und zur Rückbindung von Mitgliedern des Bundesrats an Weisungen des Landtags, in: BayVB1. 143 (2012), S. 677-682.

Hornig, Eike-Christian: Direkte Demokratie und Parteienwettbewerb - Überlegungen zu einem obligatorischen Referendum als Blockadelöser auf Bundesebene, in: ZParl 42 (2011), S. 475-492.

Hornig, Eike-Christian: Ist das abrogative Referendum in Italien ein konkordanzdemokratisches Verfahren?, in: Köppl, Stefan/Kranenpohl, Uwe (Hrsg.): Konkordanzdemokratie: ein Demokratietyp der Vergangenheit?, Baden-Baden 2012 (Tutzinger Studien zur Demokratie Bd. 2), S. 169-188.

Hornig, Eike-Christian: Risiko Volksabstimmung? Zur Kluft zwischen Parteien und Wählern bei EU-Referenden in Westeuropa im Vergleich, in: ZPol 21 (2011), S. 235-258.

Hottelier, Michel: Droits politiques, référendum législatif obligatoire, loi genevoise sur l'énergie, in: PJA 20 (2011), S. 263-269.

Hrbek, Rudolf: Die Europäische Bürgerinitiative: Möglichkeiten und Grenzen eines neuen Elements im EU-Entscheidungssystem, in: Integration 35 (2012), S. 35-50.

Hug, Simon/Spörri, Franziska: Referendums, trust, and tax evasion, in: European Journal of Political Economy 27 (2011), S. 120-131.

Hugh-Jones, David: Why Elected Politicians Implement Direct Democracy, in: Gijsenbergh, Joris/Hollander, Saskia/Houwen, Tim/de Jong, Wim (Hrsg.): Creative Crises of Democracy, Berlin/Frankfurt a.M. 2012 (Philosophy \& Politics Bd. 23), S. 421-437. 
Institut français d'opinion publique: Le référendum sur l'Europe du 23 avril 1972: 40 ans après, retour sur le premier référendum sur la construction européenne, Paris 2012.

Jebsen, Nina: Bleibe treu! Agitation während der europäischen Volksabstimmungen 19201921, Sønderborg 2012.

Jebsen, Nina: Volksabstimmung in Europa 1920/1921: Plakate als Mittel der Agitation, in: Grenzfriedenshefte 59 (2012), S. 99-112.

Jung, Otmar: Die Reform der direkten Demokratie in Berlin 2006 (Teil I), in: JdD 3 (2011), S. 259-294.

Jung, Otmar: Direkte Demokratie und Föderalismus, in: Härtel, Ines (Hrsg.): Handbuch Föderalismus - Föderalismus als demokratische Rechtsordnung und Rechtskultur in Deutschland, Europa und der Welt, Bd. II, Berlin/Heidelberg 2012, § 35, S. 223-248.

Jung, Otmar: Stuttgart 21 und die Direkte Demokratie. Kritische Anmerkungen zum Umgang mit dem Ergebnis der Volksabstimmung, in: RuP 48 (2012), S. 11-17.

Jungherr, Andreas/Jürgens, Pascal: E-Petitionen in Deutschland: Zwischen niedrigschwelligem Partizipationsangebot und quasi-plebiszitärer Nutzung, in: ZParl 42 (2011), S. 523537.

Kammel, Arnold H.: Reinventing ideas and approaches to pan-European direct democracy, in: Pichler, Johannes W./Kaufmann, Bruno (Hrsg.): Modern transnational democracy. How the 2012 launch of the European Citizens' Initiative can change the world, Wien u.a. 2012 (Schriften zur Rechtspolitik Bd. 33), S. 63-81.

Kaufmann, Bruno: Transnational Citizens' Initiative - How Modern Direct Democracy can make the European Union a Better Place for Minorities, in: Marxer, Wilfried (Hrsg.): Direct Democracy and Minorities, Wiesbaden 2012 (Direct Democracy in Modern Europe), S. 230-244.

Kersting, Norbert: Vom Musterwähler zum Wutbürger? Politische Beteiligung im Wandel, Münster 2012.

Kielmansegg, Peter Graf: Thesen zur ,direkten Demokratie“, in: Baus, Ralf Thomas/Montag, Tobias (Hrsg.): Perspektiven und Grenzen ,direkter Demokratie“, Sankt Augustin 2012, S. 9-12.

Kissane, Bill: Is the Irish Referendum a Majoritarian Device?, in: Marxer, Wilfried (Hrsg.): Direct Democracy and Minorities, Wiesbaden 2012 (Direct Democracy in Modern Europe), S. 145-154.

Klein, Hans H.: Plebiszit und Verfassung. Die plebiszitäre Abstinenz des Grundgesetzes, in: Die politische Meinung 57 (2012), S. 10-14.

Knaut, Annette: Die Entstehung transnationaler Diskursräume durch die Europäische Bürgerinitiative, in: Neue soziale Bewegungen 25 (2012), S. 37-47.

Knemeyer, Franz-Ludwig: Wenn Bürger begehren: Bilanz und Ausblick nach 16 Jahren Bürgerbeteiligung, in: BayVB1. 142 (2011), S. 681-686.

König, Thomas/Finke, Daniel: In the Aftermath of the Negative Referendums: The Irish Resistance, in: Finke, Daniel u.a. (Hrsg.): Reforming the European Union: Realizing the Impossible, Princeton u.a. 2012, S. 170-187.

König, Thomas/Finke, Daniel: Why (Unpopular) Leaders Announce Popular Votes, in: Finke, Daniel u.a. (Hrsg.): Reforming the European Union: Realizing the Impossible, Princeton u.a. 2012, S. 129-150.

Komáromi, László: Unmittelbare Demokratie in Ungarn - deutsche Träume, ungarische Realität, in: Neumann, Peter/Renger, Denise (Hrsg.): Sachunmittelbare Demokratie im inter- 
disziplinären und internationalen Kontext 2010/2011. Mittel- und Osteuropa, BadenBaden 2012 (Studien zur Sachunmittelbaren Demokratie Bd. 11), S. 139-172.

Kost, Andreas: Direkte Demokratie, 2. Aufl. Wiesbaden 2012.

Kost, Andreas: Mehr direkte Demokratie in den Kommunen?, in: Remmert, Barbara (Hrsg.): Die Zukunft der kommunalen Selbstverwaltung, Stuttgart 2012 (Schriften zur politischen Landeskunde Baden-Württembergs Bd. 39), S. 130-143.

Krause, Rolf Friedrich: Popular Votes and Independence for Montenegro, in: Marxer, Wilfried (Hrsg.): Direct Democracy and Minorities, Wiesbaden 2012 (Direct Democracy in Modern Europe), S. 22-30.

Kriesi, Hanspeter: Conclusion, in: ders. (Hrsg.): Political Communication in Direct Democratic Campaigns: Enlightening or Manipulating?, Basingstoke u.a. 2012 (Challenges to Democracy in the 21st Century), S. 225-240.

Kriesi, Hanspeter: Direct democracy: the Swiss experience, in: Geissel, Brigitte/Newton, Kenneth (Hrsg.): Evaluating democratic innovations: curing the democratic malaise?, London 2012, S. 39-55.

Kriesi, Hanspeter: Political Communication: An Integrated Approach, in: ders. (Hrsg.): Political Communication in Direct Democratic Campaigns: Enlightening or Manipulating?, Basingstoke u.a. 2012 (Challenges to Democracy in the 21st Century), S. 1-16.

Kriesi, Hanspeter (Hrsg.): Political Communication in Direct Democratic Campaigns: Enlightening or Manipulating?, Basingstoke u.a. 2012 (Challenges to Democracy in the 21st Century).

Kriesi, Hanspeter: The Role of Predispositions, in: ders. (Hrsg.): Political Communication in Direct Democratic Campaigns: Enlightening or Manipulating?, Basingstoke u.a. 2012 (Challenges to Democracy in the 21st Century), S. 143-167.

Kriesi, Hanspeter/Bernhard, Laurent: The Context of the Campaigns, in: Kriesi, Hanspeter (Hrsg.): Political Communication in Direct Democratic Campaigns: Enlightening or Manipulating?, Basingstoke u.a. 2012 (Challenges to Democracy in the 21st Century), S. $17-38$.

Krings, Günter: Die Grenzen der „direkten Demokratie“ aus parlamentarischer Sicht, in: Baus, Ralf Thomas/Montag, Tobias (Hrsg.): Perspektiven und Grenzen „direkter Demokratie“, Sankt Augustin 2012, S. 13-24.

Krishnakumar, Jaya/Müller, Tobias: The political economy of immigration in a direct democracy: The case of Switzerland, in: European Economic Review 52 (2012), S. 174-189.

Kropp, Sabine: Föderale Ordnung und Volksgesetzgebung, in: Baus, Ralf Thomas/Montag, Tobias (Hrsg.): Perspektiven und Grenzen „direkter Demokratie“, Sankt Augustin 2012, S. 79-93.

Kühling, Jürgen/Wintermeier, Florian: Die Bauleitplanung als Gegenstand plebiszitärer Bürgerbeteiligung, in: DVB1. 127 (2012), S. 317-325.

Kühling, Jürgen/Wintermeier, Florian: Die Bürgerschaft als Akteur der Bauleitplanung. Direktdemokratische Elemente als lästiges Hemmnis oder notwendiges Korrektiv hoheitlicher Planungen?, in: Kühling, Jürgen/Sebastian, Steffen (Hrsg.): Immobilienwirtschaft zwischen Ökonomie und Recht. Festschrift zum 80. Geburtstag von Dr. Dr. h.c. Dr. h.c. Johann Vielberth, Köln 2012, S. 115-130.

Kühne, Jörg-Detlef/Neumann, Peter/Schmidt, Christopher (Hrsg.): Direkte Demokratie unter Berücksichtigung der Kommunen der Weimarer Republik, überarbeiteter Nachdruck von 
Lee Seifert Greene, „Direct Legislation in Germany, Austria and Danzig“, Baden-Baden 2012 (Studien zur Sachunmittelbaren Demokratie Bd. 10).

Küpper, Herbert: Ungarn - Verfassungsgerichtsurteil 7/2012. (III.1.) AB über die Zulässigkeit von Volksinitiativen und über das Wohnen im öffentlichen Raum, in: Osteuropa 58 (2012), S. 113-114.

Laponce, Jean: Le référendum de souveraineté. Comparaisons, critiques et commentaires, Quebec 2010.

Lehner, Roman: Direkte Demokratie und Gruppenrechte : Probleme der Kollektivierung individueller Partizipation in plebiszitären Rechtsetzungsverfahren, in: Junge Wissenschaft vom Öffentlichen Recht e.V. (Hrsg.): Kollektivität - Öffentliches Recht zwischen Gruppeninteressen und Gemeinwohl, Baden-Baden 2012 (52. Assistententagung Öffentliches Recht Hamburg 2012), S. 271-291.

Leibfried, Stephan: Deutsche EU-Volksabstimmung: Therapie oder Teil des Problems?, in: Wirtschaftsdienst 92 (2012), S. 426-427.

Leinen, Jo: Die Europäische Bürgerinitiative: ein wichtiger Schritt in Richtung europäische Öffentlichkeit, in: Neue soziale Bewegungen 25 (2012), S. 28-32.

Leisner, Walter: Stuttgart 21: „Wir sind das Volk!“ - Wer?, in: NJW 64 (2011), S. 33-36.

Leukart, Raphael: Das Bürgerbegehren und der Bürgerentscheid in der Sächsischen Gemeindeordnung ( $\S 24,25$ SächsGemO), Frankfurt a.M. 2012 (Dresdner Schriften zum Öffentlichen Recht Bd. 11).

Lewis, Daniel C.: Direct democracy and minority rights. A critical assessment of the tyranny of the majority in the American states, London u.a. 2012.

Lindgren, Karl-Oskar/Persson, Thomas: Participatory governance in the EU. Enhancing or endangering democracy and efficiency?, New York 2011.

Lintschinger, Clemens: Die Europäische Bürgerinitiative, Wien 2012.

Löhle, Claudia: Direkte Demokratie - Motor oder Bremse für die Energiewende?, in: eNewsletter Wegweiser Bürgergesellschaft 10/2012 vom 25.5.2012.

Maaser, Nicola: A note on the direct democracy deficit in two-tier voting, in: Mathematical social sciences 63 (2012), S. 174-180.

Maple, Rasza/Kurnik, Andre: The Occupy Movement in Žižek's Hometown: Direct Democracy and a Politics of Becoming, in: American Ethnologist 39 (2012), S. 238-258.

Marcinkowski, Frank/Donk, André: Winning without Victory? The Media Coverage of Minority Affairs in Swiss Direct Democratic Campaigns, in: Marxer, Wilfried (Hrsg.): Direct Democracy and Minorities, Wiesbaden 2012 (Direct Democracy in Modern Europe), S. 194-211.

Marquis, Lionel/Schaub, Hans-Peter/Gerber, Marlène: The Fairness of Media Coverage in Question: An Analysis of Referendum Campaigns on Welfare State Issues in Switzerland, in: SPSR 17 (2011), S. 128-163.

Marxer, Wilfried (Hrsg.): Direct Democracy and Minorities, Wiesbaden 2012 (Direct Democracy in Modern Europe).

Marxer, Wilfried: Direkte Demokratie in Liechtenstein, in: Neumann, Peter/Renger, Denise (Hrsg.): Sachunmittelbare Demokratie im interdisziplinären und internationalen Kontext 2009/2010. Deutschland, Liechtenstein, Österreich, Schweiz und Europa, Baden-Baden 2012 (Studien zur Sachunmittelbaren Demokratie Bd. 9), S. 95-115. 
Marxer, Wilfried: Minorities and Direct Democracy in Liechtenstein, in: Marxer, Wilfried (Hrsg.): Direct Democracy and Minorities, Wiesbaden 2012 (Direct Democracy in Modern Europe), S. 165-180.

Meier, Horst: Ist das Volk klüger als seine Stellvertreter? Plebiszite und Parlamentarismus, in: ders., Protestfreie Zonen?, Berlin 2012, S. 255-259.

Meyer, Hans: Volksabstimmungen im Bund: Verfassungslage nach Zeitgeist?, in: JZ 67 (2012), S. 538-546.

Milic, Thomas: Kontextfaktoren der Heuristikverwendung bei Sachabstimmungen, in: Neumann, Peter/Renger, Denise (Hrsg.): Sachunmittelbare Demokratie im interdisziplinären und internationalen Kontext 2009/2010. Deutschland, Liechtenstein, Österreich, Schweiz und Europa, Baden-Baden 2012 (Studien zur Sachunmittelbaren Demokratie Bd. 9), S. $133-153$.

Morel, Laurence: Referendum, in: Rosenfeld, Michel/Sajó, András (Hrsg.): The Oxford Handbook of Comparative Constitutional Law, Oxford 2012, S. 501-528.

Morelli, Michele: La democrazia partecipativa nella governance dell'Unione europea, Mailand 2011.

Mozumder, Pallab/Berrens, Robert P.: Social context, financial stakes and hypothetical bias: an induced value referendum experiment, in: Applied Economics 43 (2011), S. 44874499.

Müller-Franken, Sebastian: Plebiszitäre Gesetzgebung in das Grundgesetz?, in: Neumann, Peter/Renger, Denise (Hrsg.): Sachunmittelbare Demokratie im interdisziplinären und internationalen Kontext 2009/2010. Deutschland, Liechtenstein, Österreich, Schweiz und Europa, Baden-Baden 2012 (Studien zur Sachunmittelbaren Demokratie Bd. 9), S. 48-72.

Müller-Franken, Sebastian: Referendum versus Volksgesetzgebung, in: Baus, Ralf Thomas/ Montag, Tobias (Hrsg.): Perspektiven und Grenzen „direkter Demokratie“, Sankt Augustin 2012, S. 51-70.

Mutz, Diana C.: Hearing the other side. Deliberative versus participatory democracy, Cambridge 2011.

Neumann, Peter: Gesetzgebungstechnik und direkte Demokratie in Deutschland. Plädoyer für eine Neuordnung der Volksgesetzgebung und der qualifizierten Massenpetitionen im Landesverfassungsrecht in Deutschland, in: ders./Renger, Denise (Hrsg.): Sachunmittelbare Demokratie im interdisziplinären und internationalen Kontext 2009/2010. Deutschland, Liechtenstein, Österreich, Schweiz und Europa, Baden-Baden 2012 (Studien zur Sachunmittelbaren Demokratie Bd. 9), S. 13-28.

Neumann, Peter/Renger, Denise (Hrsg.): Sachunmittelbare Demokratie im interdisziplinären und internationalen Kontext 2009/2010. Deutschland, Liechtenstein, Österreich, Schweiz und Europa, Baden-Baden 2012 (Studien zur Sachunmittelbaren Demokratie Bd. 9).

Neumann, Peter/Renger, Denise (Hrsg.): Sachunmittelbare Demokratie im interdisziplinären und internationalen Kontext 2010/2011. Mittel- und Osteuropa, Baden-Baden 2012 (Studien zur Sachunmittelbaren Demokratie Bd. 11).

Niedobitek, Matthias: Sachunmittelbare Demokratie in der Slowakischen Republik, in: Neumann, Peter/Renger, Denise (Hrsg.): Sachunmittelbare Demokratie im interdisziplinären und internationalen Kontext 2010/2011. Mittel- und Osteuropa, Baden-Baden 2012 (Studien zur Sachunmittelbaren Demokratie Bd. 11), S. 101-116.

Nierth, Claudine: Mehr Demokratie wagen: was das Volk begehrt, in: Betrifft Justiz 2012, Nr. 110, S. 272-274. 
Obermann, Holger: Entwicklung direkter Demokratie im Ländervergleich, in: LKV 22 (2012), S. 241-248.

Oppermann, Kai: The Transnational Spillovers from Pledging EU Referendums: The Case of the European Constitution, in: Marxer, Wilfried (Hrsg.): Direct Democracy and Minorities, Wiesbaden 2012 (Direct Democracy in Modern Europe), S. 215-229.

Paus, Martin/Schmidt, Ansgar: Das Grundgesetz und die direkte Demokratie auf staatlicher und kommunaler Ebene, in: JA 44 (2012), S. 48-52.

Pállinger, Zoltán Tibor: Direct Democracy, the Rule of Law and the Protection of Minorities: The Case of Hungary, in: Marxer, Wilfried (Hrsg.): Direct Democracy and Minorities, Wiesbaden 2012 (Direct Democracy in Modern Europe), S. 91-105.

Pestalozza, Christian: Volkszuständigkeiten im Grundgesetz, in: Bonner Rechtsjournal 1 (2012), S. 18-25.

Phuong, Nguyen-Hoang: Fiscal effects of budget referendums: evidence from New York school districts, Public Choice 150 (2012), S. 77-95.

Pichler, Johannes W.: The Commission's Regulation Proposal on the European Citizens' Initiative, in: Marxer, Wilfried (Hrsg.): Direct Democracy and Minorities, Wiesbaden 2012 (Direct Democracy in Modern Europe), S. 245-251.

Pichler, Johannes W./Kaufmann, Bruno (Hrsg.): Modern transnational democracy. How the 2012 launch of the European Citizens' Initiative can change the world, Wien u.a. 2012 (Schriften zur Rechtspolitik Bd. 33).

Platter, Julia: Volksinitiative, Volksbegehren und Volksentscheid zu Gegenständen der politischen Willensbildung (Art. 76-78 LV), in: Fritsch, Gunter (Hrsg.): 20 Jahre Landesverfassung. Festschrift des Landtages Brandenburg, Berlin 2012, S. 113-133.

Plottka, Julian: Bürgerbeteiligung gegen die Krise? Möglichkeiten und Grenzen der Europäischen Bürgerinitiative, in: Neue soziale Bewegungen 25 (2012), S. 17-28.

Plottka, Julian: Die Europäische Bürgerinitiative: Inklusion neuer Akteure in die europäische Politik?, in: ZParl 43 (2012), S. 419-428.

Poier, Klaus: Neue Belebung der sachunmittelbaren Demokratie in Österreich? Aktuelle Trends und Entwicklungen, in: Neumann, Peter/Renger, Denise (Hrsg.): Sachunmittelbare Demokratie im interdisziplinären und internationalen Kontext 2009/2010. Deutschland, Liechtenstein, Österreich, Schweiz und Europa, Baden-Baden 2012 (Studien zur Sachunmittelbaren Demokratie Bd. 9), S. 116-132.

Ponzano, Paolo: Ein Initiativrecht sui generis: die Europäische Bürgerinitiative, in: Neue soziale Bewegungen 25 (2012), S. 33-37.

Portmann, Marco/Stadelmann, David/Eichenberger, Reiner: District magnitude and representation of the majority's preferences: Evidence from popular and parliamentary votes, in: Public Choice 151 (2012), S. 585-610.

Proelß, Alexander/Bajić, Zlatko: Bedeutung, Ausprägungen und Grenzen der direkten Demokratie im Völkerrecht, in: JdD 3 (2011), S. 79-101.

Quittkat, Christine: Die EBI - (k)ein Tor zur europäischen Politik für „Normalbürger“, in: Neue soziale Bewegungen 25 (2012), S. 69-79.

Rademacher, Patrick/Gerth, Matthias A./Siegert, Gabriele: Media Organizations in DirectDemocratic Campaigns, in: Kriesi, Hanspeter (Hrsg.): Political Communication in Direct Democratic Campaigns: Enlightening or Manipulating?, Basingstoke u.a. 2012 (Challenges to Democracy in the 21st Century), S. 93-107. 
Ramin, Ralf/Röttger, Claudia: Der direkt gewählte Landrat in Brandenburg. Ein Akteur neuer Qualität auf kommunaler Ebene?, in: DVP 63 (2012), S. 17-24.

Ramsauer, Peter: Bewusstsein für Infrastrukturprojekte schärfen. Für eine neue Kultur der Bürgerbeteiligung, in: Bitburger Gespräche in München. Planen, erklären, zuhören - Wie Großprojekte mit Bürgerbeteiligung möglich werden, Tübingen 2012, S. 125-137.

Randolph, Gregory M.: The voter initiative and the power of the governor: evidence from campaign expenditures, in: Constitutional Political Economy 22 (2011), S. 265-286.

Riedel, Sabine: Sachunmittelbare Demokratie in Bulgarien, in: Neumann, Peter/Renger, Denise (Hrsg.): Sachunmittelbare Demokratie im interdisziplinären und internationalen Kontext 2010/2011. Mittel- und Osteuropa, Baden-Baden 2012 (Studien zur Sachunmittelbaren Demokratie Bd. 11), S. 189-209.

Rinne, Jonathan R.: Die multivariate Themen-Wahl. Überlegungen zu einem neuen direktdemokratischen Instrument, Berlin 2012 (Neue Wege der Demokratie Bd. 6).

Roca, René u.a. (Hrsg.): Wege zur direkten Demokratie in den schweizerischen Kantonen, Zürich 2012 (Schriften zur Demokratieforschung Bd. 3).

Roeder, Tina: Probleme der Ausgestaltung des Europäischen Bürgerbegehrens - auf dem Weg zur EU-Verordnung 211/2011, in: Neumann, Peter/Renger, Denise (Hrsg.): Sachunmittelbare Demokratie im interdisziplinären und internationalen Kontext 2009/2010. Deutschland, Liechtenstein, Österreich, Schweiz und Europa, Baden-Baden 2012 (Studien zur Sachunmittelbaren Demokratie Bd. 9), S. 198-224.

Roggemann, Herwig: Entwicklung und Probleme direkter Demokratie in Südosteuropa - aus vergleichender Sicht, in: Neumann, Peter/Renger, Denise (Hrsg.): Sachunmittelbare Demokratie im interdisziplinären und internationalen Kontext 2010/2011. Mittel- und Osteuropa, Baden-Baden 2012 (Studien zur Sachunmittelbaren Demokratie Bd. 11), S. 3582.

Rohner, Gabriela: Die Wirksamkeit von Volksinitiativen im Bund 1848-2010, Zürich u.a. 2012 (Schriften zur Demokratieforschung Bd. 4).

Roth, Roland: Was das Volk will. Die Beteiligungswünsche der Bürger nehmen deutlich zu wie können moderne Beteiligungsformen in einer Parteiendemokratie aussehen? In: Betrifft Justiz. 2012, Nr. 110, S. 275-278.

Salvino, Robert/Tasto, Michael T./Turnbull, Geoffrey K.: A direct test of direct democracy: New England town meetings, in: Applied Economics 44 (2012), S. 2393-2402.

Schäfer, Ansgar/Adam, Christian/Schlichenmaier, Michael: Das Plebiszit über das Bahnhofsprojekt „Stuttgart 21“. Eine Analyse der Abstimmungsergebnisse in den Stadt- und Landkreisen Baden-Württembergs, in: ZPol 22 (2012), S. 187-213.

Schäfer, Peter/Bartenschlager, Martin: Die Europäische Bürgerinitiative - Neue Beteiligungsmöglichkeiten für Europas Zivilgesellschaft, in: Publicus [Der Online-Spiegel für das Öffentliche Recht] 2011.6, S. 8-10.

Schär, Sebastian: „Impfzwang“ zwischen Medizin und Politik. Das Referendum gegen das eidgenössische Epidemiengesetz 1882, Diss. phil. Basel 2011.

Schaub, Lukas: Die Finanzierung von Wahl- und Abstimmungskämpfen. Ein Beitrag zur demokratischen Diskurs und zur politischen Chancengleichheit, Zürich/St. Gallen 2012.

Schefold, Dian: Mehr Demokratie und Probleme direkter Demokratie in Deutschland, in: ders.: Bewahrung der Demokratie. Ausgewählte Aufsätze, Berlin 2012, S. 375-387; zuerst in: Heußner, Hermann K./Huber, Roman/Jung, Otmar (Hrsg.): Das Kuratorium für Mehr Demokratie. Roland Geitmann zum 70. Geburtstag, Berlin 2011, S. 58-65. 
Schiller, Theo: Direkte Demokratie. Die mühsame Öffnung zum Volksentscheid, in: Braun, Stephan (Hrsg.): Die verstimmte Demokratie. Moderne Volksherrschaft zwischen Aufbruch und Frustration, Wiesbaden 2012, S. 199-207.

Schiller, Theo: The Emergence of Direct Democracy - a Typological Approach, in: Marxer, Wilfried (Hrsg.): Direct Democracy and Minorities, Wiesbaden 2012 (Direct Democracy in Modern Europe), S. 33-46.

Schiller, Theo: Volksinitiativen/,Citizens' Initiatives“, in: Neue soziale Bewegungen 25 (2012), S. 55-65.

Schläppi, Daniel: Politische Riten, Ämterkauf und geschmierte Plebiszite: Ritualisierter Ressourcentransfer in der Alten Eidgenossenschaft (17. und 18. Jahrhundert), in: Kitts, Margo/Schneidmüller, Bernd/Schwedler, Gerald/Kulke, Hermann (Hrsg.): State, Power, and Violence, Wiesbaden 2010 (Ritual Dynamics and the Science of Ritual Bd. 3), S. 293315 .

Schmidt, Christopher: Bürgerbegehren und Bürgerentscheid im mittel- und süddeutschen Raum der Weimarer Republik, in: Neumann, Peter/Renger, Denise (Hrsg.): Sachunmittelbare Demokratie im interdisziplinären und internationalen Kontext 2009/2010. Deutschland, Liechtenstein, Österreich, Schweiz und Europa, Baden-Baden 2012 (Studien zur Sachunmittelbaren Demokratie Bd. 9), S. 73-92.

Schmitz, Holger: Volksgesetzgebung: Eine kritische Analyse am Beispiel des Gesetzes für die vollständige Offenlegung von Geheimverträgen zur Teilprivatisierung der Berliner Wasserbetriebe, in: DVB1. 127 (2012), S. 731-737.

Schneider, Friedrich/Teobaldelli, Désirée: Beyond the Veil of Ignorance: The Influence of Direct Democracy on the Shadow Economy, München 2012 (CESifo Working Paper No. 3749).

Schoen, Harald: Wählen und abstimmen - zwei Seiten einer Medaille? Eine Analyse am Beispiel des Volksentscheids zum Nichtraucherschutz in Bayern, in: Rüdiger Schmitt-Beck (Hrsg.): Wählen in Deutschland, Baden-Baden 2012 (Politische Vierteljahresschrift, Sonderheft 45), S. 514-535.

Schott, Stéphane: L'initiative populaire dans les États Fédérés Allemands. Contribution à la connaissance d'une institution démocratique, Paris 2012.

Setälä, Maija/Schiller, Theo (Hrsg.): Citizens' initiatives in Europe. Procedures and consequences of agenda-setting by citizens, Basingstoke u.a. 2012.

Slavov, Atanas: National challenges to a transnational participatory instrument, in: Pichler, Johannes W./Kaufmann, Bruno (Hrsg.): Modern transnational democracy. How the 2012 launch of the European Citizens' Initiative can change the world, Wien u.a. 2012 (Schriften zur Rechtspolitik 33), S. 83-93.

Stadelmann, David/Portmann, Marco/Eichenberger, Reiner: Evaluating the median voter model's explanatory power, in: Economic Letters 114 (2012), S. 312-314.

Stadelmann, David/Torgler, Benno: Bounded Rationality and Voting Decisions Exploring a 160-Year Period, München 2012 (CESifo Working Paper No. 3907).

Stender-Vorwachs, Jutta: Neue Formen der Bürgerbeteiligung, in: NVwZ 31 (2012), S. 10611066.

Stone, Amy L.: Gay rights at the ballot box, Minneapolis 2012.

Strauch, Christian-Daniel: Direkte Demokratie in der Republik Moldau, in: Neumann, Peter/Renger, Denise (Hrsg.): Sachunmittelbare Demokratie im interdisziplinären und inter- 
nationalen Kontext 2010/2011. Mittel- und Osteuropa, Baden-Baden 2012 (Studien zur Sachunmittelbaren Demokratie Bd. 11), S. 221-251.

Stüttgen, Johannes: Das Grundrecht auf Einkommen und die „Direkte Demokratie“, in: Werner, Götz W. (Hrsg.): Das Grundeinkommen: Würdigung - Wertungen - Wege, Karlsruhe 2012, S. 347-371.

Süssmuth, Rita: Demokratie - mangelt es an Offenheit und Bürgerbeteiligung?, in: Das Parlament, Beilage 44-45 (2011), S. 3-7.

Taillon, Patrick: Le référendum expression directe de la souveraineté du peuple? Essai critique sur la rationalisation de l'expression référendaire en droit comparé, Paris 2012.

Talpien, Julien: Schools of democracy. How ordinary citizens (sometimes) become competent in participatory budgeting institutions, Colchester 2011.

Theuer, Karina: Durch Referenden bestätigte Amnestiegesetze in Fällen gewaltsamen Verschwindenlassens unvereinbar mit der Amerikanischen Menschenrechtskonvention. Das Urteil des Inter-Amerikanischen Gerichtshofs für Menschenrechte in der Sache Gelman v. Uruguay, in: EuGRZ 39 (2012), S. 682-693.

Thürer, Daniel: Direkte Demokratie - eine Form des Widerstands?, in: v. Arnim, Hans Herbert (Hrsg.): Widerstand, Berlin 2012 (Schriftenreihe der Hochschule Speyer Bd. 215), S. 6373.

Tierney, Stephen: Constitutional referendums. A theory of republican deliberation, Oxford 2012 (Oxford constitutional theory).

Tkaczyńsky, Jan Wiktor: Die Verankerung von Institutionen der unmittelbaren Demokratie im polnischen Verfassungssystem, in: Neumann, Peter/Renger, Denise (Hrsg.): Sachunmittelbare Demokratie im interdisziplinären und internationalen Kontext 2010/2011. Mittelund Osteuropa, Baden-Baden 2012 (Studien zur Sachunmittelbaren Demokratie Bd. 11), S. 173-186.

Töller, Annette Elisabeth/Pannowitsch, Sylvia/Kuscheck, Céline/Mennrich, Christian: Direkte Demokratie und Schulpolitik. Lehren aus einer politikfeldanalytischen Betrachtung des Scheiterns der Hamburger Schulreform, in: ZParl 42 (2011), S. 503-523.

Tridimas, George: A political economy perspective of direct democracy in ancient Athens, in: Constitutional Political Economy 22 (2011), S. 58-82.

Tschentscher, Axel/Blonski, Dominika: Direkte Demokratie in der Schweiz - Länderbericht 2010/2011, in: JdD 3 (2011), S. 139-174.

Tschopp, Silvia Serena: Politische Systembildung aus dem Geist der Geschichte: Zu den kulturellen Wurzeln der direkten Demokratie in der Schweiz, in: JdD 3 (2011), S. 41-64.

Uechtritz, Michael: Neue Formen der Bürgerbeteiligung? Planung und Zulassung von Projekten in der parlamentarischen Demokratie, in: Anwaltsblatt 62 (2012), S. 697-703.

Unger, Stefan: Gestern, heute, morgen - Direkte Demokratie in Großbritannien, in: JdD 3 (2011), S. 235-258.

Velikanov, Cyril: Deliberatively enhanced European Citizens' Initiative, in: Pichler, Johannes W./Kaufmann, Bruno (Hrsg.): Modern transnational democracy. How the 2012 launch of the European Citizens' Initiative can change the world, Wien u.a. 2012 (Schriften zur Rechtspolitik Bd. 33), S. 95-114.

Vlad, Monica: Direkte Demokratie in Rumänien, in: Neumann, Peter/Renger, Denise (Hrsg.): Sachunmittelbare Demokratie im interdisziplinären und internationalen Kontext 2010/ 2011. Mittel- und Osteuropa, Baden-Baden 2012 (Studien zur Sachunmittelbaren Demokratie Bd. 11), S. 211-219. 
Vodička, Karel: Plebiszite in Tschechien. Ein wertvolles - unzureichend eingesetztes - Konsolidierungsinstrument, in: Neumann, Peter/Renger, Denise (Hrsg.): Sachunmittelbare Demokratie im interdisziplinären und internationalen Kontext 2010/2011. Mittel- und Osteuropa, Baden-Baden 2012 (Studien zur Sachunmittelbaren Demokratie Bd. 11), S. 117137.

Voronina, Ekaterina: What can Citizens Initiate? The problems of defining the scope and limits of the European Citizens' Initiative, in: Pichler, Johannes W./Kaufmann, Bruno (Hrsg.): Modern transnational democracy. How the 2012 launch of the European Citizens' Initiative can change the world, Wien u.a. 2012 (Schriften zur Rechtspolitik Bd. 33), S. 123127.

de Vrese, Claes H./Semetko, Holli A.: Political Campaigning in Referendums. Framing the Referendum Issue, London 2010.

Waldhoff, Christian: Der Finanzvorbehalt, in: Baus, Ralf Thomas/Montag, Tobias (Hrsg.): Perspektiven und Grenzen ,direkter Demokratie“, Sankt Augustin 2012, S. 71-78.

Waldhoff, Christian/v. Aswege, Hanka: Direkte Demokratie und Staatsfinanzkrise - Abschaffung der Finanztabus als Ausweg?, in: JdD 3 (2011), S. 9-39.

Wälti, Sarah: Emotionalisierungsstrategien im Abstimmungskampf um Schengen/Dublin, Freiburg/Ue. 2012.

Weder, Rolf/Grubel, Herbert G.: A Note on Political Contestability and the Future of the European Union, in: Kyklos 65 (2012), S. 408-423.

Wehling, Hans-Georg: Direkte Demokratie, in: Drews, Albert (Hrsg.): Die Wiederentdeckung der Politik?! Perspektiven des Parteienstaates, Alternativen im Parteienstaat, RehburgLoccum 2012, S. 47-55.

Wendt, Garmin: Referenden unerwünscht. Eine Untersuchung der Kontroversen zur Einführung von Volksabstimmungen in den Niederlanden, Münster u.a. 2010.

Weßels, Thomas: Rechtliche Beurteilung der Ausnahmetatbestände und deren Umgehungsgefahr bei Bürgerbegehren und Bürgerentscheid, Baden-Baden 2012 (Kommunalrecht Kommunalverwaltung Bd. 59).

Wheatley Jonathan: The Disruptive Potential of Direct Democracy in Deeply Divided Societies, in: Marxer, Wilfried (Hrsg.): Direct Democracy and Minorities, Wiesbaden 2012 (Direct Democracy in Modern Europe), S. 64-73.

Wirth, Werner/Matthes, Jörg/Schemer, Christian: When Campaign Messages Meet Ideology: The Role of Arguments for Voting Behaviour, in: Kriesi, Hanspeter (Hrsg.): Political Communication in Direct Democratic Campaigns: Enlightening or Manipulating?, Basingstoke u.a. 2012 (Challenges to Democracy in the 21st Century), S. 188-204.

Wirth, Werner/Schemer, Christian/Kühne, Rinaldo/Matthes, Jörg: The Impact of Positive and Negative Affects in Direct-Democratic Campaigns, in: Kriesi, Hanspeter (Hrsg.): Political Communication in Direct Democratic Campaigns: Enlightening or Manipulating?, Basingstoke u.a. 2012 (Challenges to Democracy in the 21st Century), S. 205-224.

Wittreck, Fabian: Ausgewählte Entscheidungen zur direkten Demokratie, in: JdD 3 (2011), S. 295-321.

Wrase, Michael: Direkte Demokratie und Nachhaltigkeit - ein Beitrag aus verfassungsrechtlicher Perspektive, in: JdD 3 (2011), S. 103-125.

Wulfhorst, Reinhard: Konsequenzen aus „Stuttgart 21“: Vorschläge zur Verbesserung der Bürgerbeteiligung, in: DÖV 64 (2011), S. 581-590. 
Wyn Jones, Richard/Scully, Rodger: Wales says yes: devolution and the 2011 Welsh referendum, Cardiff 2012.

Ziekow, Jan: Neue Formen der Bürgerbeteiligung? Planung und Zulassung von Projekten in der parlamentarischen Demokratie, in: Ständige Deputation des Deutschen Juristentages (Hrsg.): Verhandlungen des 69. Deutschen Juristentages, Bd. 1 Teil D, München 2012, S. D3-D157.

Ziekow, Jan: Neue Formen der Bürgerbeteiligung? Planung und Zulassung von Projekten in der parlamentarischen Demokratie, in: NJW Beilage 2012, S. 91-94. 
